\title{
BIOACTIVITIES AND CHEMOPROFILING COMPARISONS OF CHENOPODIUM AMBROSIOIDES L. AND CHENOPODIUM BOTRYS L. GROWING IN KASHMIR, INDIA
}

\author{
SHAMEEM A SHAMEEM ${ }^{1,2}$, KHALIQUZ Z KHAN ${ }^{1}$, AJAZ A WAZA ${ }^{3}$, ABDUL HASEEB SHAH ${ }^{4}$, HAFSA QADRI $^{4}$, \\ BASHIR A GANAI ${ }^{3 *}$
}

${ }^{1}$ Department of Chemistry, University of Kashmir, Srinagar, Jammu and Kashmir, India. ${ }^{2}$ Department of Chemistry, Islamia College of Science and Commerce, Srinagar, Jammu and Kashmir, India. ${ }^{3}$ Centre of Research for Development, University of Kashmir, Srinagar, Jammu and Kashmir, India. ${ }^{4}$ Department of Bioresources, University of Kashmir, Srinagar, Jammu and Kashmir, India. Email: bbcganai@gmail.com

Received: 12 July 2018, Revised and Accepted: 05 September 2018

ABSTRACT

Objectives: The objectives of the study were the gas chromatography-mass spectrometry (GC-MS) identification and comparison of the chemical constituents, evaluation of the antifungal and anticancer activities of two species of genus Chenopodium, for example, Chenopodium ambrosioides (Ca) and Chenopodium botrys $(\mathrm{Cb})$ growing in Kashmir, Himalayan region.

Methods: The hydrodistilled essential oil of Ca and Cb was subjected to GC-MS analysis and antifungal activity for minimum inhibitory concentration (MIC) determination against different human pathogenic fungal strains using broth microdilution assay in 96-well microtiter plates as per the protocol of the clinical and laboratory standards institute (2008 M27-A3). The anti-proliferative ability of the essential oils was also evaluated against the two cell lines MCF-7 (human mammary carcinoma cells) and A549 (Human lung adenocarcinoma epithelial cells).

Results: A total of 34 compounds identified in Ca with $\alpha$-terpinene (37.17\%), isoascaridole (20.48\%), and ascaridole (14.83\%) as the key compounds. The key compounds of $\mathrm{Cb}$ were shyobunol (18.91\%), and hedycaryol (9.51\%), germacrene-D-4-ol (8.57\%), with 65 identified compounds. Both the species were found to have comparable antifungal activities against human pathogenic fungi with $\mathrm{MIC}_{80}$ values in the range of $0.031 \mathrm{mg} / \mathrm{ml}-$ $0.256 \mathrm{mg} / \mathrm{ml}$ for $\mathrm{Ca}$ and $0.031 \mathrm{mg} / \mathrm{ml}-0.126 \mathrm{mg} / \mathrm{ml}$ in case of Cb. Maximum anti-proliferative activity was observed at $125 \mu \mathrm{g} / \mathrm{ml}$ concentration in A549 cell line, while as the oils inhibited the growth of MCF-7 cell line at a lower concentration of $31.25 \mu \mathrm{g} / \mathrm{ml}$.

Conclusion: The essential oils of $\mathrm{Ca}$ and $\mathrm{Cb}$ were found to have potent anticancer and antifungal activities and can have potential use as a natural fungicide.

Keywords: Gas chromatography-mass spectrometry, Chenopodium ambrosioides, Chenopodium botrys, Ascaridole, $\alpha$-Terpenene, Shyobunol.

(c) 2019 The Authors. Published by Innovare Academic Sciences Pvt Ltd. This is an open access article under the CC BY license (http://creativecommons. org/licenses/by/4. 0/) DOI: http://dx.doi.org/10.22159/ajpcr.2019.v12i1.28418

\section{INTRODUCTION}

The genus Chenopodium belongs to family Chenopodiaceae and includes about 150 species which are annual herbs or bushy plants growing in semiarid to arid regions and have resistance to adverse climate [1]. The chemical investigations have been carried out on the essential oils of Chenopodium species [2] and are reportedly found to contain number of compounds such as ecdysteroids [3], flavonoids [4], sesquiterpenes [5], and saponins [6]. In India, the genus is reportedly represented by 21 species, and some are cultivated for vegetables and grains [7]. Chenopodium species have significance due to their broad area of medicinal applications in traditional medicine as anthelmintic, antispasmodic, emmenagogue, stomachic, for pain in amenorrhea, diaphoretic, abortifacient and for catarrh, asthma, and migraine [8,9]. Chenopodium album is reported to possess antileishmanial activity against Leishmania donovani in inbred BALB/c mouse [10].

Chenopodium ambrosioides (Ca) is an aromatic herb widely distributed throughout India and is found growing in Kashmir, Central Punjab, West Bengal, Bihar, Maharashtra, the Deccan, and eastern Ghats [11] in moist undisturbed waste places as a weed [12]. The extract and essential oil of this plant species are used as anthelmintic due to the presence of ascaridole [13]. The essential oil of Ca is known to possess allelopathic activity [14], and its aqueous extract is considered a blood purifier, stimulant, and cures hypothermia [15].

Chenopodium botrys $(\mathrm{Cb})$ is a strongly aromatic medicinal plant growing in dry sandy areas in the temperate Himalayas from Kashmir to Sikkim [16]. Cb finds use in multiple therapeutic applications such as expectorant, anticonvulsant, antibacterial, and tonic [17]. In Kashmir Himalayas, an ethnomedicinal survey indicates that the seed decoction of the plant is used relieves a headache due to gallbladder troubles, for treating tapeworm infestation in children [18], anthelmintic, diuretic, liver diseases, and laxative [19]. In Tibetan medicine, $\mathrm{Cb}$ is used to treat stomach and liver problems [20].

As part of the research program on the phytochemical screening of the medicinal plants from Kashmir, investigations were carried out on the essential oil isolated from the two Chenopodium species, for example, $\mathrm{Ca}$ and $\mathrm{Cb}$ by gas chromatography-mass spectrometry (GC-MS) analysis and evaluated the antifungal and anti-proliferative activity as no previous studies on the oils of these two plant species growing in Kashmir has been reported. The study will help in finding the phytochemicals from the two plant species growing in temperature Himalayan region and to evaluate their antifungal and anticancer efficacies.

\section{METHODS}

\section{Plant material}

The fresh aerial parts of $\mathrm{Ca}$ and $\mathrm{Cb}$ were collected locally in the month of August 2017. The plants were identified by taxonomist at Centre for Biodiversity and Taxonomy, University of Kashmir and Voucher specimens of $\mathrm{Ca}$ (KASH-2628) and $\mathrm{Cb}$ (KASH-2629) have been deposited in Kashmir University herbarium. The light yellow colored essential oils were isolated by carrying out the hydrodistillation of 
the fresh aerial parts of the two plant species for $3 \mathrm{~h}$ using Clevenger apparatus [21]. The isolated essential oils were dried by placing over anhydrous sodium sulfate.

\section{GC-MS analysis}

GC-MS analysis of the Chenopodium essential oils was carried out using GC-MS Shimadzu QP-2010 system with an Rtx-5 column $(30 \mathrm{~m} \times 0.25 \mathrm{~mm}$ $\mathrm{id} \times 0.25 \mu \mathrm{m}$ film thickness). The injector temperature was $260^{\circ} \mathrm{C}$. Oven temperature program was held at $50^{\circ} \mathrm{C}$ for $2 \mathrm{~min}$, heating at $3^{\circ} \mathrm{C}$ and keeping the temperature constant at $210^{\circ} \mathrm{C}$ for $10 \mathrm{~min}$ and from $210^{\circ} \mathrm{C}$ to $250^{\circ} \mathrm{C}$ at $6^{\circ} \mathrm{C} / \mathrm{min}$ with a hold time of $31 \mathrm{~min}$. Carrier gas used was helium. Pressure $69 \mathrm{kPa}$, total flow $137.3 \mathrm{~mL} / \mathrm{min}$, column flow $1.21 \mathrm{~mL} / \mathrm{min}$, linear velocity $39.9 \mathrm{~cm} / \mathrm{s}$, purge flow $3.0 \mathrm{~mL} / \mathrm{min}$, split ratio: 110.0 ; ion source temperature $230^{\circ} \mathrm{C}$; and interface temperature $270^{\circ} \mathrm{C}$. Injection volume was $0.3 \mu \mathrm{l}$. The MS scan parameters include EI ionization voltage of $70 \mathrm{eV}$ and spectra were recorded in the mass range of $40-650 \mu$.

The identification of the compounds in the essential oils was based on mass spectral comparisons with those of NIST 11 (National Institute of Standards and Technology, US and WILEY 8) library [22,23].

\section{Cell culture and in vitro antiproliferative assay}

Human cancer cell lines (MCF-7 and A549) were purchased from National Centre for Cell Science (Pune, India). The cells were grown in Dulbecco's modified eagle's medium, supplemented with $10 \%$ fetal bovine serum, and $1 \%$ penicillin-streptomycin at $37^{\circ} \mathrm{C}$ in a humidified incubator containing 5\% $\quad \mathrm{CO}_{2}$. (3-(4,5-dimethylthiazol-2-yl)- 2,5 diphenyltetrazolium bromide, a tetrazole) (MTT) assay was performed to determine the anticancer activity of the oils [24].

For this purpose, MCF-7 and A549 cells were seeded at $10^{4}$ cells/well and allowed to grow overnight. Next day, the media were replaced with $200 \mu \mathrm{l}$ of the fresh medium before treatment with oils. Both the oils were prepared in dimethyl sulfoxide (DMSO) and cells were treated with different concentrations $(15.6,31.25,62.5,125,250$, and $500 \mu \mathrm{g} / \mathrm{ml}$ ) of the oil. After $12 \mathrm{~h}$ treatment, cell growth was evaluated by MTT assay. MTT solution of $50 \mu \mathrm{l}(5 \mathrm{mg} / \mathrm{ml}$ of PBS) was added to each well, and the plates were incubated for $3 \mathrm{~h}$ at $37^{\circ} \mathrm{C}$ in the dark. The media were aspirated, and $150 \mu$ of MTT solvent (DMSO) was added to each well to solubilize the formazan crystals. The absorbances of plates were measured on enzyme-linked immunosorbent assay reader (Benchmark, BioRad) at a wavelength of $570 \mathrm{~nm}$. The sample was performed in triplicate, and the experiment was repeated thrice.

\section{Evaluation of antifungal activity}

The antifungal activities of chenopodium essential oils (in terms of their minimum inhibitory concentration [MIC]) against different human pathogenic fungal strains were evaluated by broth microdilution assay using 96-well microtiter plates.

Broth microdilution assay was done according to the protocol of the Clinical and Laboratory Standards Institute [25]. The essential oils were serially diluted two-fold in the successive wells of the 96-well plates starting from well 1 to $10.100 \mu \mathrm{l}$ of the fungal cell suspension $\left(0.1 \times 10^{5}\right.$ O.D. $)$ was inoculated in each well of the 96 -well plate except the $12^{\text {th }}$ column, wherein $200 \mu$ of media was poured, which serves as media control. The $11^{\text {th }}$ column containing only $100 \mu \mathrm{l}$ media and $100 \mu \mathrm{l}$ of cell suspension served as a drug-free control. The plates were incubated at $30^{\circ} \mathrm{C}$ for $48 \mathrm{~h}$. The cell growth was assessed either using microtiter plate reader or by naked eye visualization.

\section{RESULTS}

The essential oils with light yellow color obtained by hydrodistillation of the aerial parts of $\mathrm{Ca}$ and $\mathrm{Cb}$ growing in Kashmir were obtained in the yield of $0.35 \% \mathrm{w} / \mathrm{v}$ and $0.23 \% \mathrm{w} / \mathrm{v}$, respectively, of the fresh weight basis.

The GC-MS analysis of Ca from Kashmir Himalayan region, results in the identification of 34 compounds (Table 1) accounting to the total percentage of $95.78 \%$ of the total oil composition with highest percentage of monoterpene hydrocarbons (52.54\%) followed by oxygenated monoterpenes (38.95\%), esters (1.37\%), oxygenated sesquiterpenes $(0.41 \%)$, and miscellaneous compounds $(2.51 \%)$. The major compounds of the essential oil of Ca are $\alpha$-terpinene (37.17\%), isoascaridole (20.48\%), ascaridole (14.83\%), and p-cymene (11.76\%).

The essential of $\mathrm{Cb}$ consists of 65 identified compounds (Table 2), comprising (94.32\%) of the total oil with the dominance of oxygenated sesquiterpenes (49.82\%), followed by sesquiterpenes (25.74\%), monoterpene hydrocarbons $(11.56 \%)$, esters $(3.71 \%)$, and others $(3.49 \%)$. The major compounds from this species are shyobunol (18.91\%), hedycaryol (9.51\%), germacrene-D-4-ol (8.57\%), $\delta$-cardinene (4.90\%), cardin-4-en-10-ol (4.42\%), geranyl acetate (3.56\%), limonene (3.47\%), and 1-methyl-5-methylene-1,6-cyclohexadiene $(2.85 \%)$.

Anticancer activity of the essential oils was determined using MTT assay. Results of the antiproliferative activity showed maximum growth inhibitions at $125 \mu \mathrm{g} / \mathrm{ml}$ against A549 cell line (Fig. 1) while as the oils inhibited the growth of MCF-7 cell line at a lower concentration of $31.25 \mu \mathrm{g} / \mathrm{ml}$.

The essential oils of $\mathrm{Ca}$ and $\mathrm{Cb}$ inhibited the growth of seven tested Candida species, Candida albicans, Candida glabrata, Candida parapsilosis, Candida kefyr, Candida tropicalis, Candida dubliniensis, and Candida krusei. The $\mathrm{MIC}_{80}$ ranges from 0.031 to $0.252 \mathrm{mg} / \mathrm{ml}$ for $\mathrm{Ca}$ essential oil and 0.126 to $0.252 \mathrm{mg} / \mathrm{ml}$ for $\mathrm{Cb}$ essential oil.

The $\mathrm{MIC}_{80}$ of Chenopodium essential oils against the tested fungal strains are shown in Table 3.

\section{DISCUSSION}

GC-MS analysis of the essential oils of the two species reveals a total of 92 identified compounds from both the species with only seven compounds being common to the two species. The results indicate that there are greater qualitative and quantitative differences between the oils of the two species and also between the oils of the same species which are previously investigated. These differences can be due to the difference of chemotypes and variability of the subspecies and difference in climatic and the geographical areas of the plant growth.

Seven different chemotypes: Ascaridole, $\alpha$-terpenene, $\alpha$-pinene, p-cymene, carvacrol, limonene, and $\alpha$-terpinyl acetate are reported to occur in Ca [26]. The results of the present investigation of the oil

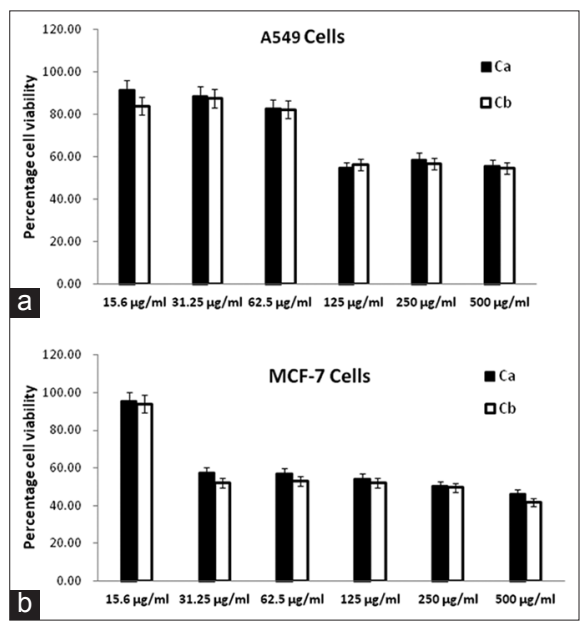

Fig. 1: Anticancer activity of the oils of Chenopodium ambrosioides and Chenopodium botrys. (a) (3-(4,5-dimethylthiazol-2-yl)- 2,5 diphenyltetrazolium bromide, a tetrazole) (MTT) assay results of the two essential oils against the A549 cell line. (b) MTT assay results of the two essential oils against the MCF-7 cell line 
Table 1: Chemical constituents of the essential oil of Chenopodium ambrosioides

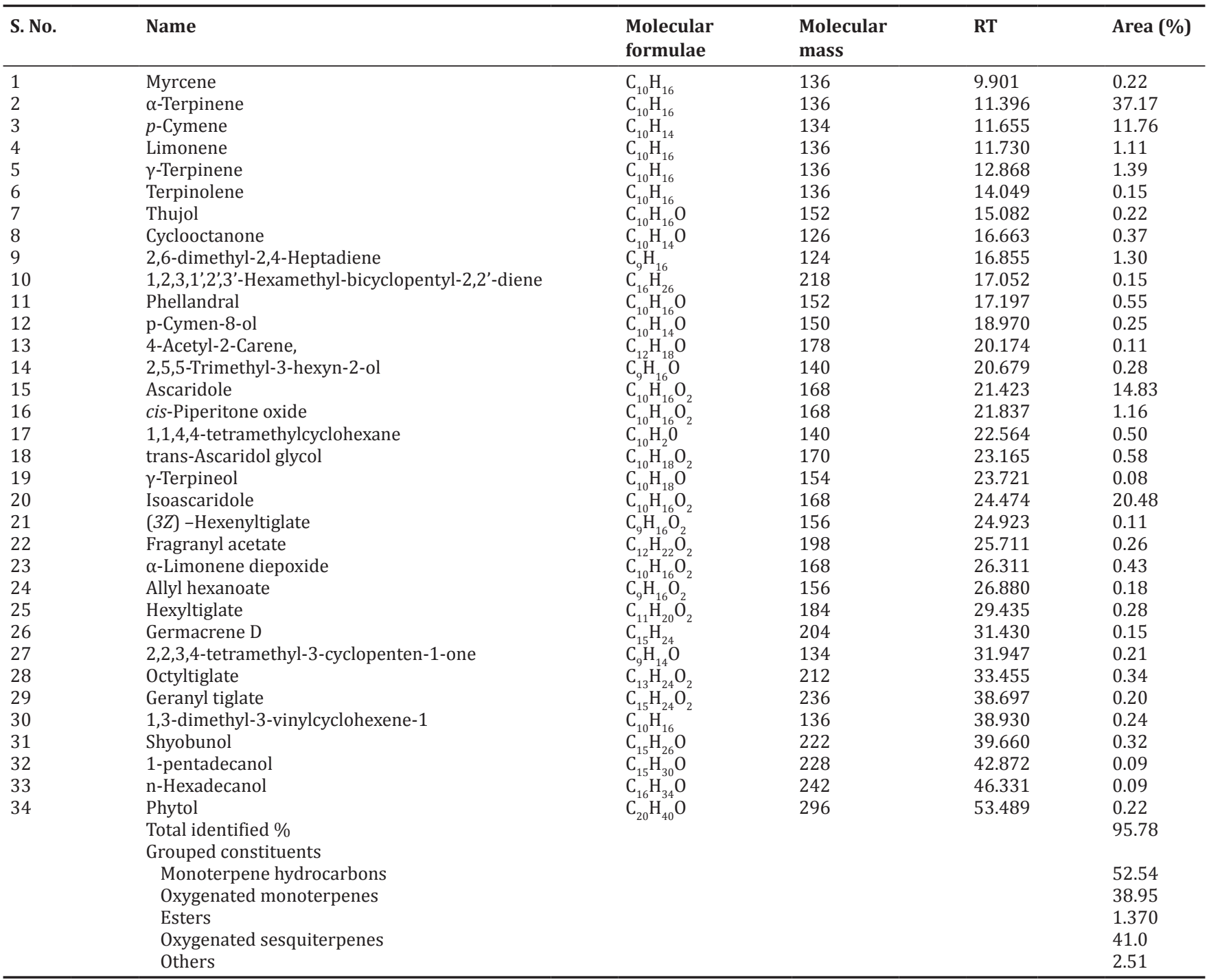

Compounds are listed in order of elution from the Rtx- 5 column. RT: Retention time

composition on $\mathrm{Ca}$ are different from the previous reports, and the present oil has been found to belong to $\alpha$-terpenene chemotype. The Ca essential oil analyzed from different parts of India is also reported to belong to $\alpha$-terpenene chemotype, with oil from Chandigarh (India) containing the major constituents as $\alpha$-terpenene (47.37\%), p-cymene (25.77\%), cis -ascaridole (14.75\%) [27], the oil from Uttarakhand containing $\alpha$-terpenene (44.68\%), p-cymene (21.28\%), ascaridole $(17.89 \%)$ [28], and the major constituents of oil from Southern Hills of India were found to be $\alpha$-terpenene (63.6\%), p-cymene (19.5\%), and ascaridole (6.2\%) [29]. Further, the Ca essential oil from Nigeria is also reported to be $\alpha$-terpenene chemotype with major constituents as $\alpha$-terpenes (63.6\%), p-cymene(26.4\%), and ascaridole (3.9\%) [26]. However, the oil from for Iran has been found to be rich in $\alpha$-terpenes (15.90\%), camphor (12.40\%), and trans-ascaridole (6.38\%) [30], and the Mexican chemotype contains limonene (31.50\%), and transpinocarveol $(26.70 \%)$ as the major constituents [31]. The Ca oil from Brazil is found richer in Z-ascaridol (61.4\%) and E-ascaridol (18.6\%) [32] and the oil from China has also been found to contain $Z$-ascaridole (27.27\%), p-cymene (19.05\%), and isoascaridole (14.15\%) [33]. The chemotype of Ca from Togo (Bangladesh) is also reported to be ascaridole type with ascaridole content of $51.12 \%$ [34].

The present results of the oil composition of $\mathrm{Cb}$ show much greater differences than the previously analyzed samples from different parts of the world. The $\mathrm{Cb}$ from Greece has been found to possess elemol acetate (16.3\%), elemol (14.1\%), and botrydiol (11.1\%) [35]. The Cb from Iran reportedly contains $\alpha$-eudesmol (15.5\%), epi- $\alpha$-muurolol (11.3\%), and cubenol (10.5\%) [36]. Another research studies from Iran revealed the presence of $\gamma$-terpineol (52.8\%), p-cymene (19.0\%), and isoascaridole $(7.0 \%)$ as the main components of the oil [30] and further one more investigation from two different localities of Iran is reportedly known to possess; juniper camphor (16.5\% and $25.7 \%)$, elemol $(14.3 \%$ and $13.4 \%$ ), and $\alpha$-cadinol (8.2\% and 11.6\%) [37]. Mahboubi et al. [38] have identified 2,3-dehydro-4-oxo- $\beta$-lonone (22.4\%), 7-epi-amiteol (11.5\%), and elemol (7.4\%) as the key compounds of Cb from Iran.

Our results show that the Chenopodium essential oils have a potent anticancer activity on A549 and MCF-7 human cancer cell lines. The oil treatment showed a concentration-dependent antiproliferative activity of the human cell lines studied. The $\mathrm{Ca}$ and $\mathrm{Cb}$ essential oils evaluation for antiproliferative activity using MTT assay revealed that both these essential oils have comparable anticancer activities and inhibit the growth of A549 cancerous cell line around 40\% at $125 \mu \mathrm{g} / \mathrm{ml}$ concentration while the growth of MCF-7 cancerous cell line was inhibited around $45 \%$ at a concentration of $31.25 \mu \mathrm{g} / \mathrm{ml}$. Previous studies on the anticancer activity of Ca have been reported for human breast cancer cells MCF-7, and the activity is observed to be dose- and time-dependent with a MIC $_{50}$ value of $9.45 \mu \mathrm{g} / \mathrm{ml}$ observed after $24 \mathrm{~h}$ 
Table 2: Chemical composition of the essential oil of Chenopodium botrys

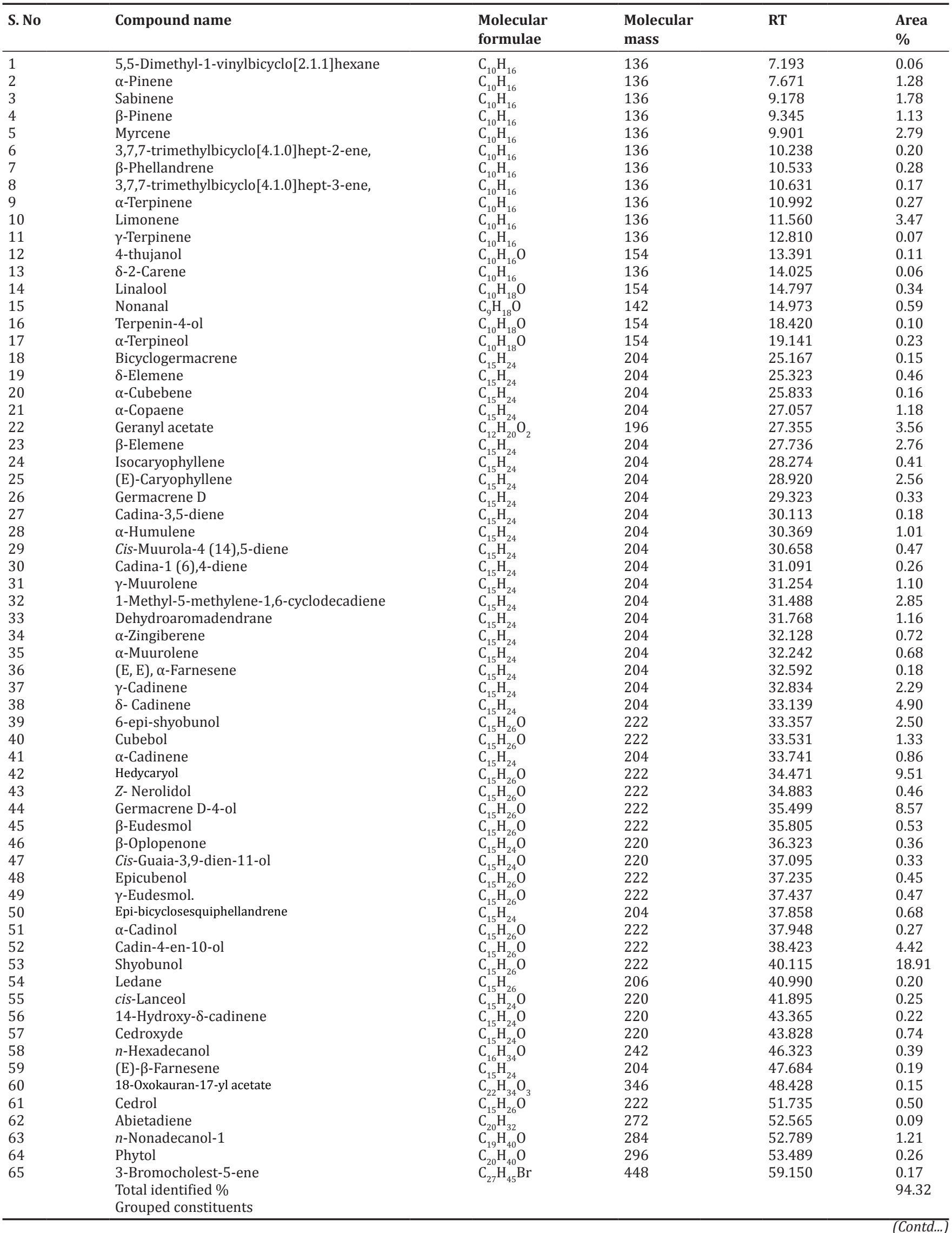


Table 2: (Continued)

\begin{tabular}{|c|c|c|c|c|c|}
\hline S. No & Compound name & $\begin{array}{l}\text { Molecular } \\
\text { formulae }\end{array}$ & $\begin{array}{l}\text { Molecular } \\
\text { mass }\end{array}$ & RT & $\begin{array}{l}\text { Area } \\
\%\end{array}$ \\
\hline & Oxygenated sesquiterpenes & & & & 49.82 \\
\hline & Sesquiterpene hydrocarbons & & & & 25.74 \\
\hline & Monoterpene hydrocarbons & & & & 11.56 \\
\hline & Oxygenated monoterpenes & & & & 0.78 \\
\hline & Diterpenes & & & & 0.35 \\
\hline & Esters & & & & 3.71 \\
\hline
\end{tabular}

Table 3: $\mathrm{MIC}_{80}{ }^{*}$ of Chenopodium ambrosioides and Chenopodium botrys essential oils, against different types of human pathogenic fungi

\begin{tabular}{|c|c|c|}
\hline Strains & $\begin{array}{l}\text { Chenopodium } \\
\text { ambrosioides } \\
\mathrm{MIC}_{80}(\mathrm{mg} / \mathrm{ml})\end{array}$ & $\begin{array}{l}\text { Chenopodium } \\
\text { botrys } \\
\text { MIC }_{80}(\mathrm{mg} / \mathrm{ml})\end{array}$ \\
\hline Candida albicans & 0.252 & 0.126 \\
\hline Candida glabrata & 0.126 & 0.126 \\
\hline Candida paropsilosis & 0.126 & 0.031 \\
\hline Candida kefyr & 0.063 & 0.126 \\
\hline Candida tropicalis & 0.063 & 0.063 \\
\hline Candida dubliniensis & 0.063 & 0.063 \\
\hline Candida krusei & 0.031 & 0.031 \\
\hline
\end{tabular}

${ }^{*} \mathrm{MIC}_{80}$ was determined following the standard Clinical Laboratory Standards Institute protocol and was performed in triplicates. MIC: Minimum inhibitory concentration

using MTT assay [39]. There are no previous reports regarding the anticancer activity of $\mathrm{Cb}$ essential oils. The work demonstrates that $\mathrm{Ca}$ and $\mathrm{Cb}$ exert antiproliferative activity against A549 and MCF-7 cell lines, but the constituents responsible for the activity and their mechanism of antiproliferative activity needs to be evaluated.

$\mathrm{Ca}$ and $\mathrm{Cb}$ possess good antifungal activity against the tested fungal strains and the antifungal activities of the essential oils, of the two species, are comparable. MIC $_{80}$ results depict that $\mathrm{Ca}$ is more active against $C$. krusei while $\mathrm{Cb}$ shows potent anticandidal activity against C. krusei and C. parapsilosis strains. It is not possible to compare the anticandidal activity of the two Chenopodium essential oils as no previous investigations have been carried out on the anticandidal activity of $\mathrm{Ca}$ and $\mathrm{Cb}$ essential oils. However, the antifungal activity of $\mathrm{Ca}$ against different Aspergillus species has been reported, and it has been proposed that ascaridole is the principal fungiotoxic compound [32]. The present data along with the absence of ascaridole in $\mathrm{Cb}$ having comparable anticandidal activity with Ca suggest that the anticandidal activity may also involve other major and minor oxygenated sesquiterpene compounds that have a synergistic effect.

\section{CONCLUSION}

The chemoprofiling of the two species of the genus Chenopodium by GC-MS reveals that $\alpha$-terpenene and shyobunol are the principal compounds of $\mathrm{Ca}$ and $\mathrm{Cb}$, respectively, while $\mathrm{Ca}$ is dominated by monoterpene hydrocarbons followed by oxygenated monoterpenes, $\mathrm{Cb}$ is dominated by oxygenated sesquiterpenes followed by sesquiterpenes hydrocarbons. Both the oils show a moderate antiproliferative activity against the human cancer cell lines of varied origin. Moreover, oil extracts from both the species show potent antifungal activity against the tested human fungal pathogens.

\section{ACKNOWLEDGMENTS}

The author (SAS) thanks UGC for grant of teacher's fellowship under Faculty Development Program to carry out the research. Thanks are also due to the Director Centre of Research for Development, University of Kashmir, for providing the laboratory facility. The Principal ICSC and the Head Department of Chemistry, University of Kashmir, are also acknowledged for constant support and encouragement. AHS acknowledges funding to his laboratory from DST in the form of INSPIRE Faculty Award (DST/INSPIRE/04/2015/001575). AAW acknowledges CSIR for providing fellowship under CSIR RA scheme (9/251 (0077) 2k17). HQ acknowledges Project Assistant fellowship from INSPIRE Faculty Award.

\section{AUTHORS' CONTRIBUTIONS}

This work was carried out in collaboration between all authors. Authors Bashir Ahmad Ganai and Khaliquz Zaman Khan designed the study. Shameem A. Shameem carried out the literature survey, the isolation and chemical characterization of the oils, wrote the protocol, and the first draft of the manuscript. Authors, Abdul Haseeb Shah, Hafsa Qadri, and Ajaz A. Waza, managed the antifungal and anticancer study and wrote the respective protocols. All authors read and approved the final manuscript.

\section{CONFLICTS OF INTEREST}

The authors declare to have no conflict of interest.

\section{REFERENCES}

1. Kühn U. Chenopodiaceae. In: Kubitzki K, editors, The Families and Genera of Vascular Plants. II. Hamburg: Springer; 1993. p. 253-81.

2. Teresa J, de P, González MS, Grande M, Bellido IS. Delta-5-hydro1-hydroxy carvomenthols from the essential oil of Chenopodium multifidum. Phytochemistry 1983;22:2749-52.

3. Toth I, Bathory M, Szendrei K, Minker E, Blazso G. Ecdysteroids in Chenopodiaceae: Chenopodium album. Fitoterapia 1981;52:77-80.

4. Ibrahim LF, Kawashty SA, Baiuomy AR., Shabana MM, ElEraky WI, El-Negoumy SI. A comparative study of the flavonoids and some biological activities of two Chenopodium species. Chem Nat Compounds 2007; 43:24-8.

5. Bedrossian AG, Beauchamp PS, Bernichi B, Dev V, Kitaw KZ, Rechtshaffen $\mathrm{H}$, et al. Analysis of North American Chenopodium botrys essential oil isolation and structure of two new sesquiterpene alcohols. J Essent Oil Res 2001;13:393-400.

6. Ma WW, Heinstein PF, McLaughlin JL. Additional toxic, bitter saponins from the seeds of Chenopodium quinoa. J Nat Prod 1989;52:1132-5.

7. Yadav N, Vasudeva N, Singh, HS, Sharma SK. Medicinal properties of genus Chenopodium Linn. Nat Prod Radian 2007;6:131-4.

8. Watt JM, Breyer-Brandwijk MG. The Medicinal and Poisonous Plants of Southern and Eastern Africa. $2^{\text {nd }}$ ed. London UK: E and S Liningstone Ltd; 1962.

9. Vasishita PC. Taxonomy of Angiosperms. India: Ram Chand; 1989.

10. Kaur R, Kaur J, Kaur S, Joshi J. Evaluation of the antileishmanial efficacy of medicinal plant Chenopodium album Linn. Against experimental visceral leishmaniasis. Int J Pharm Pharm Sci 2016;8:227-31.

11. Chopra BN, Badhwar RL, Ghosh S. Poisonous Plants of India. New Delhi: ICAR; 1965.

12. Maheshwari JK. A Contribution to the flora of Kanha National Park, Madhya Pradesh. Bull Bot Surv of India 1963;5:117-40.

13. Potawale SE, Luniya KP, Mantri RA, Mehta UK, Waseem MD, Sadiq MD, et al. Chenopodium ambrosioides: An ethnopharmacological review. Pharmacologyonline 2008;2:272-86. 
14. Jimenez-Osornio FM, Kumamoto J, Wasser C. Allelopathic activity of Chenopodium ambrosioides L. Biochem Syst Ecol 1996;24:195-205.

15. Kaur M, Singhal VK, Singh J. Use Of some ethnomedicinal herbs by the natives Of Solang Valley, Kullu District, Himachal Pradesh. Int J Pharm Pharm Sci 2017;9:222-7.

16. Nadkarnin KM. Indian Materiamedica: With Ayurvedic, Unani-Tibbi, Siddha, Allopathic, Nomeopathic, Naturopathic and Home Remedies, Appendices and Indexes. 1. $3^{\text {rd }}$ ed. New delhi: Popular Prakashan; 1996.

17. Zargari A. Medicinal Plants. $6^{\text {th }}$ ed. Vol. 1. Tehran University Publications. Tehran: Tehran university Publications; 1993.

18. Singh V. Herbal remedies for worm infestation in Kashmir Himalaya. Fitotherapia 1994;65:354-6.

19. Koul MK. Medicinal plants of Kashmir and Ladakh. New Delhi: Indus Publishing Company; 1997.

20. Singh V, Kapahi BK, Srivastava TN. Medicinal herbs of Ladakh especially in home ramedies. Fitotherapia 1996;67:38-48

21. Clevenger JF. Apparatus for the determination of volatile oil. J Am Pharm Assoc 1928;17:345-9.

22. Mosmann T. Rapid colorimetric assay for cellular growth and survival: Application to proliferation and cytotoxicity assays. J Immunol Methods 1983;65:55-63.

23. Massada Y. Analysis of Essential Oils by Gas Chromatography and Mass Spectrometry. New York: Wiley; 1976.

24. Mass Spectral Library. NIST/EPA/NIH: USA; 2002. Available from: http://www.nist.gov/srd/nistla.htm.

25. Clinical and Laboratory Standards Institute (CLSI). Reference Method for Broth Dilution Antifungal Susceptibility Testing of Yeasts. $3^{\text {rd }}$ ed. Approved standard. CLSI M27-A3(28). Wayne (Pennslvania): Clinical and Laboratory Standards Institute; 2008

26. Owolabi MS, Lajide L, Oladimeji MO, Setzer WN, Palazzo MC, Olowu RA, et al. Volatile constituents and antibacterial screening of the essential oil of Chenopodium ambrosioides L. Growing in Nigeria. Nat Prod Commun 2009;4:989-92.

27. Singh HP, Batish DR, Kohli RK, Mittal S, Yadav S. Chemical composition of essential oil from leaves of Chenopodium ambrosioides from Chandigarh, India. Chem of Nat Comp 2008;44:378-9.
28. Lohani H, Chauhan NK, Kumar K, Haider SZ, Andola HC. Comparative aroma profile of wild and cultivated Chenopodium ambrosioides $L$ from Uttarakhand. J Essent Oil Bear Plants 2012;15:657-61.

29. Gupta D, Charles R, Mehta VK, Garg SN, Kumar S. Chemical examination of the essential oil of Chenopodium ambrosioides L. From the Southern Hills of India. J Essent Oil Res 2002;14:93-4.

30. Omidbaigi R, Sefidkon F, Nasrabadi FB. Essential oil content and compositions of Chenopodium ambrosioides L. J Essent Oil Bear Plants 2005;8:154-8

31. Foroughi A, Pournaghi P, Najafi F, Zangeneh MM, Zangeneh A, Moradi R. Chemical composition and antibacterial properties of Chenopodium botrys L. Essential oil. Int J Pharm Phytochem Res 2016;8:1881-5.

32. Jardim CM, Jham GN, Dhingra OD, Freire MM. Composition and antifungal activity of the essential oil of the Brazilian Chenopodium ambrosioides L. J Chem Ecol 2008;34:1213-8.

33. Bai CQ, Liu ZL, Liu QZ. Nematicidal constituents from the essential oil of Chenopodium ambrosioides aerial parts. E J Chem 2011;8:S143-8.

34. Kobaa K, Catherine G, Raynaud C, Chaumont JP, Sanda K, Laurence N. Chemical composition and cytotoxic activity of Chenopodium ambrosioides $L$. Essential oil from Togo. Bangladesh. J Sci Ind Res 2009;44:435-40.

35. Tzakou O, Pizzimenti A, Pizzimenti FC, Sdrafkakis V, Galati EM. Composition and antimicrobial activity of Chenopodium botrys $L$. Essential oil from Greece. J Essent oil Res 2006;19:292-4

36. Morteza-Semnani K, Babanezhad E. Essential oil composition of Chenopodium botrys L. from Iran. J Essent Oil Bear Plants 2007;10:314--7.

37. Feizbakh SH, Sedaghat S, Tehrani MS, Rustaiyan A. Chemical composition of essential oils of Chenopodium botrys L. From two different locations in Iran. J Essent Oil Res 2003;15:193-4.

38. Mahboubi M, Bidgoli FG, Farzin N. Chemical composition and antimicrobial activity of Chenopodium botrys L. Essential oil. J Essent Oil Bear Plants 2011;14:498-503.

39. Jia-Liang W, Dan-Wei M, Ya-Nan W, Hong Z, Bing H, Qun L, et al. Cytotoxicity of essential oil of Chenopodium ambrosioides $\mathrm{L}$ against human breast cancer MCF-7 cells. Trop J Pharm Res 2013;12:929-33. 